\title{
Antifungal Nanoformulation for Biocontrol of Tomato Root and Crown Rot Caused by Fusarium oxysporum f. sp. radicis-lycopersici
}

\author{
Ricardo Aravena ${ }^{1}$, Ximena Besoain ${ }^{1, *} \mathbb{B}$, Natalia Riquelme ${ }^{1}$, Aldo Salinas ${ }^{1}$, Miryam Valenzuela ${ }^{2}$, \\ Eduardo Oyanedel ${ }^{1}$, Wilson Barros ${ }^{1} \mathbb{D}$, Yusser Olguin ${ }^{3}$, Alejandro Madrid ${ }^{4}\left(\mathbb{D}\right.$, Matias Alvear ${ }^{5}$ and \\ Iván Montenegro $6, * \mathbb{D}$
}

check for updates

Citation: Aravena, R.; Besoain, X.; Riquelme, N.; Salinas, A.; Valenzuela, M.; Oyanedel, E.; Barros, W.; Olguin, Y.; Madrid, A.; Alvear, M.; et al. Antifungal Nanoformulation for Biocontrol of Tomato Root and Crown Rot Caused by Fusarium oxysporum $\mathrm{f}$. sp. radicis-lycopersici. Antibiotics 2021, 10, 1132. https://doi.org/10.3390/ antibiotics10091132

Academic Editor: Stefano Serra

Received: 30 August 2021

Accepted: 17 September 2021

Published: 20 September 2021

Publisher's Note: MDPI stays neutral with regard to jurisdictional claims in published maps and institutional affiliations.

Copyright: (c) 2021 by the authors. Licensee MDPI, Basel, Switzerland. This article is an open access article distributed under the terms and conditions of the Creative Commons Attribution (CC BY) license (https:/ / creativecommons.org/licenses/by/ $4.0 /)$.
1 Escuela de Agronomia, Facultad de Ciencias Agronomicas y de los Alimentos, Pontificia Universidad Catolica de Valparaiso, San Francisco s/n La Palma, Quillota 2260000, Chile; ricardo.aravenaflores@gmail.com (R.A.); natalia.riquelme@pucv.cl (N.R.); aldo.salinas@pucv.cl (A.S.); eduardo.oyanedel@pucv.cl (E.O.); wilson.barros@pucv.cl (W.B.)

2 Molecular Microbiology and Environmental Biotechnology Laboratory, Department of Chemistry \& Center of Biotechnology Dr. Daniel Alkalay Lowitt, Universidad Tecnica Federico Santa Maria, Avda. España 1680, Valparaiso 2390123, Chile; miryam.valenzuela@sansano.usm.cl

3 Centro Cientifico Tecnologico de Valparaiso-CCTVaL, Universidad Tecnica Federico Santa Maria, Avenida España 1680, Valparaiso 2340000, Chile; yusser.olguin@usm.cl

4 Laboratorio de Productos Naturales y Sintesis Organica-LPNSO, Departamento de Quimica, Facultad de Ciencias Naturales y Exactas, Universidad de Playa Ancha, Avda. Leopoldo Carvallo 270, Playa Ancha, Valparaiso 2340000, Chile; alejandro.madrid@upla.cl

5 Laboratory of Industrial Chemistry, Process Chemistry Centre, Abo Akademi University, Biskopsgatan 8, 20500 Turku/Abo, Finland; matias.alvear@abo.fi

6 Escuela de Obstetricia y Puericultura, Facultad de Medicina, Universidad de Valparaiso, Angamos 655, Reñaca, Vina del Mar 2520000, Chile

* Correspondence: ximena.besoain@pucv.cl (X.B.); ivan.montenegro@uv.cl (I.M.); Tel.: +56-32-237-2930 (X.B.)

Abstract: Tomatoes (Solanum lycopersicum L.) are the most cultivated and important vegetable crop in the world. These plants can wilt during crop growth due to fusarium wilt (fusariosis), a disease that damages tomato vascular systems. The Fusarium isolated and analyzed in this work correspond to Fusarium oxysporum f. sp. radicis-lycopersici. The isolates were molecularly identified, and analysis was done on the in vitro effects of the nanoemulsions (previously obtained from extracts of Chilean medicinal plants of the genera Psoralea and Escallonia) to inhibit mycelial and conidial germination of the isolates. Subsequently, the nanoemulsions were evaluated under greenhouse conditions for preventive control of fusariosis in the root and crown, with high levels of disease control observed using the highest concentrations of these nanoemulsions, at 250 and $500 \mathrm{ppm}$.

Keywords: Fusarium oxysporum; crown and root rot; plant extract; nanoemulsions; tomato plants

\section{Introduction}

The tomato (Solanum lycopersicum L.) is considered the most important and widely cultivated vegetable crop worldwide. Globally, production reached 4.7 million hectares (ha), equivalent to 177 million tons (t) of tomatoes in 2016 [1] with China, India and the United States being the largest producers [2]. In Chile, it is the most widely consumed vegetable, and approximately 5463 hectares are cultivated yearly for fresh tomato production [1].

One of the major production problems for growing tomato crops is fusarium wilt disease, or fusariosis, caused by the fungus Fusarium oxysporum f. sp. lycopersici (Fol) or by F. oxysporum f. sp. radicis-lycopersici (Forl). Both are morphologically indistinguishable, which can make their identification difficult $[3,4]$. These pathogens mainly infect plants by entering through the root elongation zone and through micro-wounds caused by root growth [5-7]. The availability of water facilitates entry and infection, causing symptoms 
of wilting from the basal zone to the apex of the plants by Fol, and root and crown rot by Forl [4]. The latter can also be found in asymptomatic host plants of the families: Amaranthaceae, Asteraceae, Brassicaceae, Chenopodiaceae and Poaceae [8].

From the roots, Fol moves acropetally through the xylem until it reaches the apex, where it blocks the vessels after having produced enzymes and toxins [9], whereas Forl begins by colonizing the areas where roots are growing, then moving towards the crown of the plant, and staying in that area [10]. Brown vascular lesions can be observed near the crowns of affected plants [5]. As is common in soil microorganisms, they can survive almost indefinitely in the form of chlamydospores (resistant survival structures). These pathogens can also be found in the soil as mycelium and colonizing the remains of the roots of host plants [11]. They can also be spread by tools, infected seeds, potting materials, contaminated soil, irrigation water, wind and insects [12]. Fol can cause yield losses of 21 to $47 \%$ [13], and Forl, losses of up to $78 \%$ of plants when they are grown in coconut fiber [14], since infected plants must be completely uprooted to prevent the pathogen from entering nearby plants [15].

Fusarium is a complex of fungal species. There are four forms which have been found to be especially damaging to tomato cultivation: F. o. f. sp. lycopersici races 1 , 2 and 3 (Fol: 1, 2 and 3), and F. o. f. sp. radicis-lycopersici (Forl), with race 3 and Forl causing the greatest damage [16]. The majority of commercial hybrid tomato varieties have resistance to Fol 1 and 2, but not Fol 3 nor Forl, leaving plants without resistance to these two particular forms [17].

Currently, there are no adequate curative controls, leaving preventive control as the most common method of control. However, this has not been effective. Preventive control methods include soil solarization, vaporization, and the use of fumigants such as dazomet and metham sodium, among others. Growers also frequently burn crop residues, use resistant cultivars and crop rotation, as well as chemical controls [18].

In addition to the preventive soil fumigants such as metham sodium, fungicides such as carbendazim, benomyl, and prochloraz are also used to try to control Fusarium. It has been observed that the fungicides currently being applied are not very effective in controlling Fusarium, which could be due to structural resistance or its ability to infect alternative host plants $[11,16]$. Also, the use of chemical fungicides and fumigants should be increasingly limited due to current concerns about their impacts on the environment, health and global food safety [19]. The control of both of these specific pathogens depends mainly on chemicals [20], even when reports have been made showing that they are not effective once the pathogens have entered the plant [8]. The use of resistant rootstocks has also been implemented to prevent the development of Fol race 3 [21].

Alternatively, biological control methods, integrated with cultural practices, have been shown to reduce Fusarium incidence and severity and to help in the prevention of this disease [18]. The use of cyanobacteria for biological control has been shown to decrease wilting produced by Fol [22]. Fungi such as Entrophospora colombiana, Trichoderma spp., as well as the bacterium Pseudomonas fluorescens have also been tested as possible controls [23]. The combined use of Trichoderma spp. plus biofumigation with Brassica juncea, could have synergistic effects on control of the pathogen [18].

Another alternative to chemical control is the application of plant extracts. Extracts from the Chilean Canelo (Drimys winteri Forst) tree have been tested for effects on mycelial reduction of the pathogen compared to conventional controls [9,24]. Plant extracts from Nicotiana tabacum and Chrisanthemus have demonstrated antifungal activity without causing damage or adverse effects on growing plants $[9,25]$. Certain components of these plant extracts, such as cinnemaldehyde, eugenol, allyl isothiocyanate and carvacrol have also demonstrated an inhibitory capacity against the germination and vegetative growth of spores [26].

Applications of different plant extracts can inhibit mycelial growth of Fusarium oxysporum, including at significant levels, equal to conventional chemical controls [27]. These formulations can be very simple mixtures of natural ingredients with specific activity or more 
complex mixtures. The activity of these extracts refers to their ability to act as biofungicides, as this is the major benefit provided to the plants [28].

Mycelial inhibition studies done in vitro using commonly found plant extracts have demonstrated inhibition in mycelia of Fusarium spp., Aspergillus flavus, and Rhizoctonia solani, among others, with results equal to those obtained with benomyl and surpassing both the biological controls Trichoderma and Bacillus. The secondary metabolites that have been identified as contributors to the inhibitory action are either anthraquinonic in nature, or flavonoids of a catechinic nature $[29,30]$.

At present, scientific studies on vegetable crops are moving towards nanotechnology, as the safest option for agrochemicals [31], exploring their use as antifungal agents [32] which in some cases have shown up to $100 \%$ inhibition of mycelial growth [33], with the same effects on Fusarium oxysporum conidia [34]. Nanoemulsions have been tested against Fol, revealing inhibition of this pathogen [35]. Are extracts based on Chilean medicinal plants effective for creating biopesticides that can defend tomatoes against this pathogen? Our hypothesis is that nanoemulsion formulations based on extracts from plants in the Psoralea and Escallonia genera will have a controlling effect on fusariosis in tomato plants.

To test this hypothesis, the following objectives were planned: (i) to evaluate the inhibitory effect of different plant extracts on the control of conidia in vitro for two isolates of Fusarium oxysporum f. sp. radicis-lycopersici, (ii) to evaluate the effect of nanoemulsions based on plant extracts to control fusariosis caused by F. oxysporum f. sp. radicis-lycopersici, when applied to tomato plants grown in a greenhouse.

\section{Materials and Methods}

\subsection{Obtaining and Identifying the Isolates}

The isolates used in this study were obtained from monosporic cultures from the Phytopathology Laboratory (LF) of the Pontificia Universidad Católica de Valparaíso (PUCV), in La Palma, Quillota, Región de Valparaíso, Chile. Isolates were recovered in modified MSF selective medium [36], with peptone $15 \mathrm{~g} \cdot \mathrm{L}^{-1}$, potassium phosphate $1 \mathrm{~g} \cdot \mathrm{L}^{-1}$, magnesium sulfate $0.5 \mathrm{~g} \cdot \mathrm{L}^{-1}$, granulated agar $20 \mathrm{~g} \cdot \mathrm{L}^{-1}$, penicillin $0.05 \mathrm{~g} \cdot \mathrm{L}^{-1}$, and streptomycin $0.3 \mathrm{~g} \cdot \mathrm{L}^{-1}$ added after autoclaving. Identification of the isolates was done using the PCR technique. Genomic DNA was extracted from pure cultures using the DNeasy Plant Mini Kit (Qiagen, Germany). To perform the PCR, four pairs of specific primers (Uni, Sp13, Sp23 and Sprl) were used to differentiate Fol and Forl from other special forms of F. oxysporum [37]. The amplification reactions were prepared using a final volume of $22 \mu \mathrm{L}$. The methodology followed the specifications of the SapphireAmp ${ }^{\circledR}$ Fast PCR Master Mix (Takara, Japan). One $\mu \mathrm{L}$ of DNA template was used in each reaction. All of the reactions were done using a thermocycler (Bioer, China) with the following conditions: $94{ }^{\circ} \mathrm{C}, 1 \mathrm{~min}$ (initial denaturation), followed by 35 cycles that included denaturation at $98{ }^{\circ} \mathrm{C}$ for $5 \mathrm{~s}$, alignment at $55^{\circ} \mathrm{C}$ for $5 \mathrm{~s}$, extension at 72 for $5 \mathrm{~s}$, and a final elongation at $72{ }^{\circ} \mathrm{C}$ for $1 \mathrm{~min}$. The products of the PCR were visualized through electrophoresis in a 1\% agarose gel in a TAE buffer (Winkler, Chile) stained with red gel (Biotium, USA), and visualized on a UV transilluminator (Vilber Lourmat, France). The isolates were kept in an MSF medium at $23{ }^{\circ} \mathrm{C}$ for subsequent analysis. This analysis was performed two times.

\subsection{Nanoemulsion Preparation}

The preparation of the nanoemulsions was performed by combining high-energy methods based on sonication and high-pressure homogenization. The choice of formulation components was obtained by studying the compatibilities of the extracts with different oils and subsequently, with different surfactants and co-surfactants. Based on the content of saturated fatty acids, the oils used were: coconut oil, palm oil, peanut oil and soybean oil. For the choice of surfactant, the hydrophilic-lipophilic balance (HLB) system was considered for obtaining o/w emulsions, where Polyoxyethylene(10) octyl phenyl ether (Triton X-100) was included in parallel studies, Polyoxyethylene(8) octyl phenyl ether 
(Triton X-114), polyoxyethylene sorbitan laurate (Tween 20), polyoxyethylene sorbitan palmitate (Tween 40) and polyoxyethylene sorbitan stearate (Tween 80).

Briefly, extract and oils were mixed in equal parts and stirred at room temperature for $48 \mathrm{~h}$. The mixtures were then centrifuged and filtered. The oily component was mixed with the aqueous solution containing $1 \%, 3 \%$ and $5 \%$ surfactant and the result of these mixtures was sonicated (Vibra cell ${ }^{\mathrm{TM}}$ ) for $10 \mathrm{~min}$ and then subjected to the high pressure homogenizer (EmlsiFlex-C3, Avestin Inc) for $2 \mathrm{~h}$. The obtained formulation was evaluated for transmittance by turbidimetry and the particle size was determined by Dynamic light scattering (DLS) using the Zetasizer Nano ZS system, Malvern. The stability of the nanoemulsion was determined by measuring the particle size variation after three heating-cooling cycles $\left(4^{\circ} \mathrm{C}-40^{\circ} \mathrm{C}\right)$. For all analyses, the coconut oil extract/Triton X-100 $5 \%$ (1:99) mixture was found to be the most stable, with particle sizes of $230 \mathrm{~nm}$.

\section{In Vitro Evaluation of Plant Extracts}

The Fusarium spores used in the in vitro tests were recovered from the MSF cultures using a sterile loop handle, deposited in a test tube with sterile water, and then the concentration of conidia was measured in a Neabauer chamber in order to perform a spore count under microscopy. After counting, dilutions with sterilized distilled water (SDW) were done in order to obtain $1 \times 10^{6}$ spores $\mathrm{mL}^{-1}$. The extracts from plants of the genera Psoralea and Escallonia that were used for the in vitro tests were provided by Dr. Iván Montenegro. The concentrations used were 200, 175, 150, 125, 100, 75, 50, 25, 12.5, 6.12 and $3.11 \mu \mathrm{g} \cdot \mathrm{mL}^{-1}$, which were obtained using a stock solution of $5 \mathrm{~g}$ of plant extract in $100 \mu \mathrm{L}$ of DMSO. The $3 \mathrm{~mL}$ microplates were then filled with $1200 \mu \mathrm{L}$ of MSF selective medium mixture, with the extracts added at the range of concentrations indicated above, plus $150 \mu \mathrm{L}$ of pathogen inoculum $\left[1 \times 10^{6}\right.$ spores $\left.\cdot \mathrm{mL}^{-1}\right]$.

The microplates were placed on a shaker at $130 \mathrm{rpm}$ and spore counting was done in a Neubauer chamber after $24 \mathrm{~h}$ of incubation at room temperature. This test was repeated two times.

\subsection{Tomato Plant Trials}

These experiments were done in the greenhouse areas of the LF-PUCV. The tomatoes were grown in a heated greenhouse, at $25^{\circ} \mathrm{C} \pm 3{ }^{\circ} \mathrm{C}$. The variety used was Naomi, from seeds provided by the Semillas Latinoamericanas S.A. company. The seedlings were started in 50 cell speedling trays and grown for 21 days $(72 \mathrm{~mL}$ volume) until being transplanted into $5 \mathrm{~L}$ pots with substrate composed of coconut fiber and black peat (Kekkilä profesional, Europe) (1:1).

For fertigation of the plants, the nutritive solution [38] was used, consisting of the following macronutrients in mmol. $\mathrm{L}^{-1}: 1.25 \mathrm{NH}_{4}{ }^{+}, 8.75 \mathrm{~K}^{+}, 4.25 \mathrm{Ca}^{2+}, 2.0 \mathrm{Mg}^{2+}, 13.75 \mathrm{NO}_{3}{ }^{-}$, $1.25 \mathrm{H}_{2} \mathrm{PO}_{4}{ }^{-}$and $3.75 \mathrm{SO}_{4}{ }^{2-}$, with a $\mathrm{pH}$ of 5.8 , and an $\mathrm{EC}$ of $2.3 \mathrm{dS} \cdot \mathrm{m}^{-1}$, delivered through an emitter of $2 \mathrm{~L} \cdot \mathrm{h}^{-1}$ in an open system, maintaining $30 \%$ humidity.

When the plants reached a height of $100 \mathrm{~cm}$, treatments of $100 \mathrm{~mL}$ of nanoemulsion from plant extracts, at concentrations of 125, 250 and $500 \mathrm{ppm}$, were applied to the areas surrounding the plant stems. Three days after treatment, $100 \mathrm{~mL}$ of inoculum $\left[1 \cdot 10^{6}\right.$ spores $\left.\cdot \mathrm{mL}^{-1}\right]$ was added per plant. In addition, a chemical treatment was done using dazomet at the dosage recommended by the distributor $\left(35 \mathrm{~g} \cdot \mathrm{m}^{-2}\right)$. A non-inoculated control treatment (negative control) with the pathogen (T00) and a treatment with water plus inoculum (T0), were also done, applying the pathogens in the manner described above.

\subsection{Statistical Analysis}

Four blocks, six treatments and six plants were used as the experimental units. The variables evaluated were height of the plant and length of the necrotic streaks in the xylem.

This experiment was done using a Randomized Complete Block Design (RCBD), to which an Analysis of Variance (ANOVA, $p \leq 0.05$ ) was applied, followed by a Tukey's Test for means separation, using the statistical program GraphPad Prism 8.0.1. 


\section{Results}

\subsection{Identification of Isolates}

The fungal isolates PUCVToF 1667 and PUCVToF 1915, were obtained from the LFPUCV fungal collection, and identified using the methodology of Hirano and Arie [37]. For the isolate PUCVToF 1667, PCR products were obtained with the specific primers Uni and Sp23, therefore it would correspond to Forl. For the isolate PUCVToF 1915, PCR products were obtained with the specific primers Uni, Spl12 and Sp23, which corresponds to Forl, plus an additional band that could correspond to race 2 of Fol (Table 1; Figure 1).

Table 1. Identification of the Isolates. Bands from the PCR amplification of four specific primers for differentiation of the Fol and Forl races, according to the methodology of Hirano and Arie [37]. Analysis performed twice. ${ }^{1}(+)$ : Presence of amplification; $(-)$ : Absence of amplification.

\begin{tabular}{cccccc}
\hline Primer Set & Uni & Sp13 & Sp23 & Sprl & Result \\
\hline PUCVToF 1667 & $+{ }^{1}$ & - & - & + & Forl \\
PUCVToF 1915 & + & - & + & + & Forl + race 2 \\
\hline
\end{tabular}

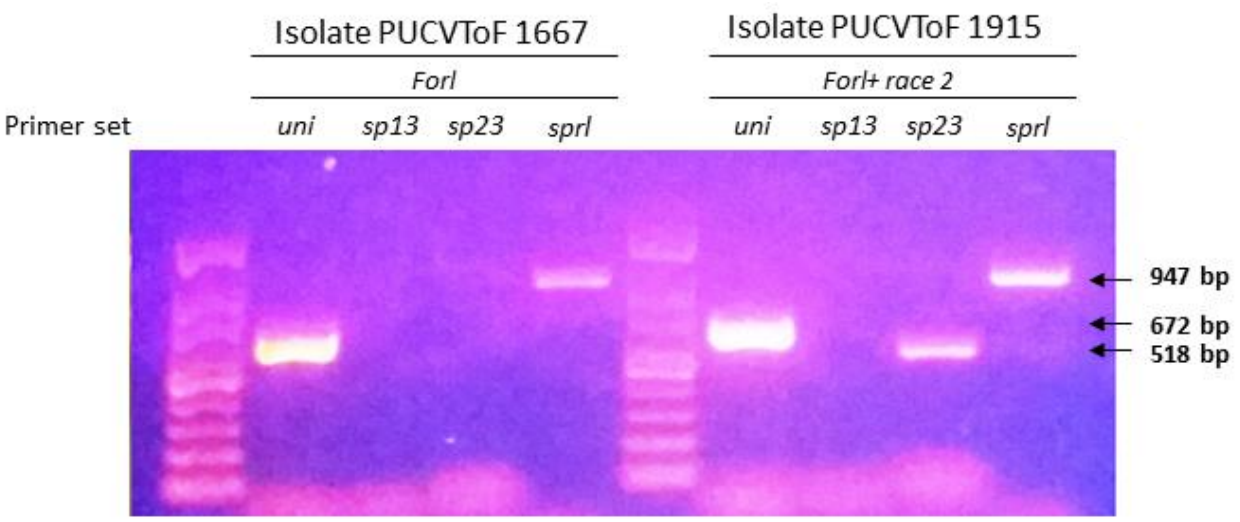

Figure 1. Identification of isolates PUCVToF 1667 and PUCVToF 1915 by polymerase chain reaction (PCR) with the uni, sp13, sp23, and sprl primer sets [37]. PCR products were electrophoresed in a 1.0\% agarose gel and stained with red gel. The arrows show the size of the amplicons obtained.

\subsection{In Vitro Evaluation of Plant Extracts on Fusarium Oxysporum Spore Germination}

From the in vitro trials of the Psoralea and Escallonia genera plant extracts mixed with dichloro and ethyl acetate, arranged on microplates with MSF medium in decreasing concentrations from 200 to $75 \mathrm{~g} \cdot \mathrm{mL}^{-1}$, it was determined that extract 4 showed reduced spore viability and a greater control of conidia. Greater control $(>80 \%)$ was observed for extract 4 at concentrations of 200 g.mL ${ }^{-1}$ (Figure 2).

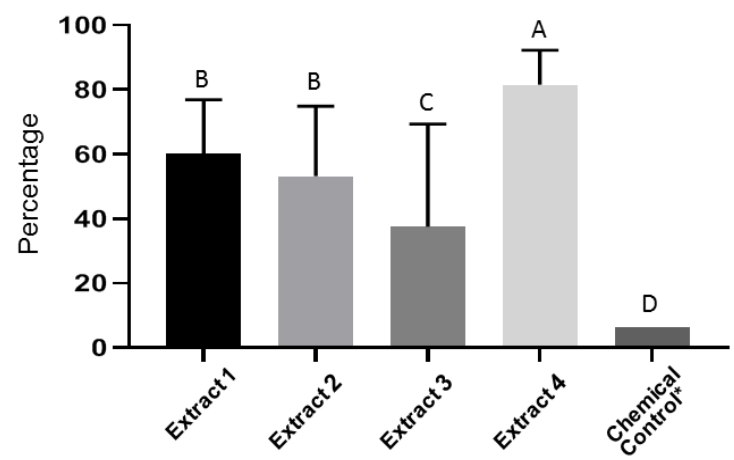

Figure 2. Effect of plant extracts on Forl spore germination. The highest percentage of inhibition was observed in the treatment with extract 4 at $200 \mathrm{~g} \cdot \mathrm{mL}^{-1}$. Means with different letters indicate significant differences from each other $(p \leq 0.05)$. 


\subsection{Greenhouse Trials}

In relation to results from the two greenhouse trials (where the two Forl isolates were independently inoculated), the occurrence of disease development attributable to Fusarium was observed. The affected plants in both trials showed dark brown vascular lesions around the crown and main roots [39], basal leaves infected with severe chlorosis, and production of adventitious roots (Figure 3). The trials in pots with decreasing nanoemulsion treatment concentrations of 500, 250 and $125 \mathrm{ppm}$, showed effects on the advance of the pathogen in comparison to the inoculated control treatment (Figure 3).

(a)

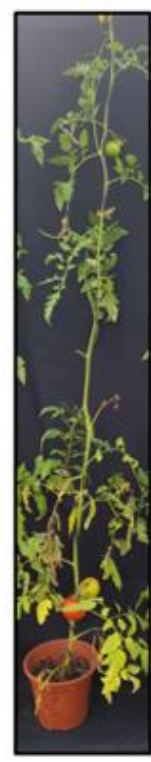

Negative control

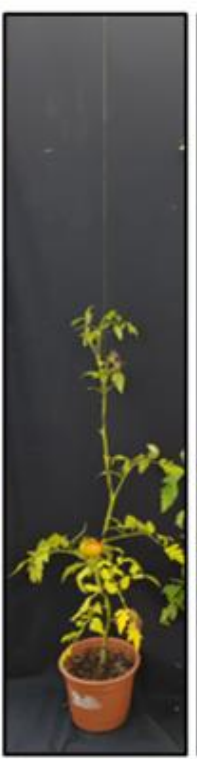

Inoculated control

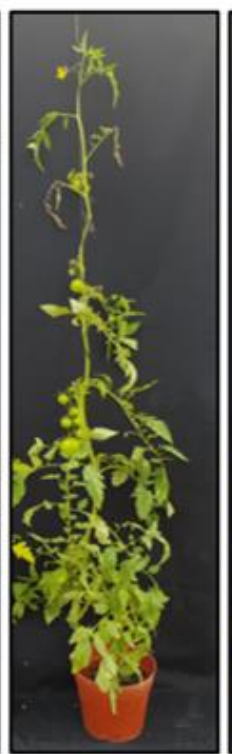

$125 \mathrm{ppm}$

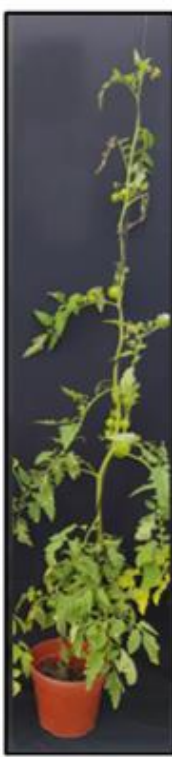

$250 \mathrm{ppm}$

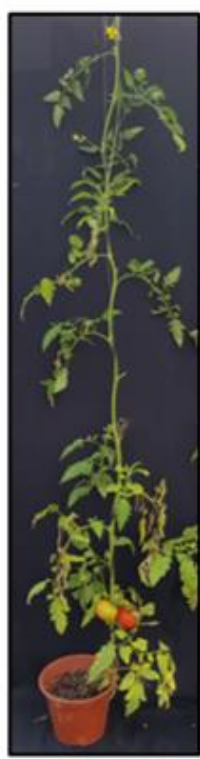

500 ppm

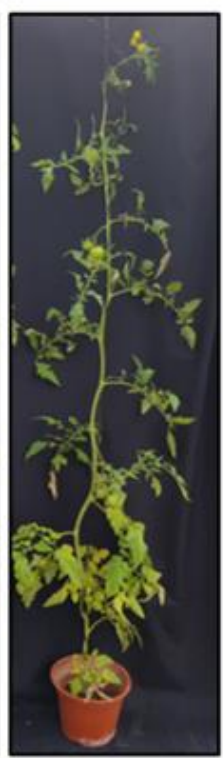

Chemical Control
(Dasomet) (b)

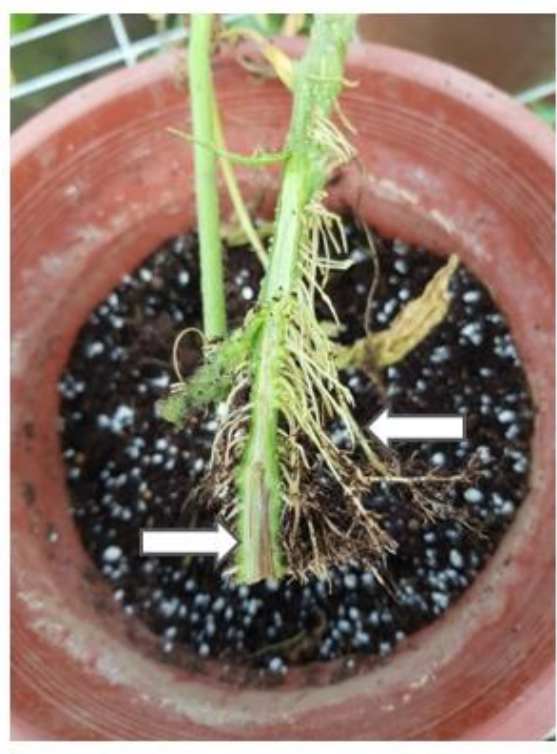

Figure 3. (a) Tomato plants cv. Naomi affected by Forl. The effects of three concentrations of nanoemulsion (125 ppm, $250 \mathrm{ppm}$, and $500 \mathrm{ppm}$ ), in comparison with two controls, one inoculated with Forl, and an uninoculated, negative control, plus a conventional chemical treatment (dazomet). (b) Detail of vascular browning in the xylem tissue and abundant root proliferation.

For the plants inoculated with Forl + 2 (PUCVToF 1915) and treated with $500 \mathrm{ppm}$ of the nanoemulsion, decreased necrotic lesions were observed, which were statistically equal to the negative control (Figure 4a). The 125 and $250 \mathrm{ppm}$ treatments also decreased the advance of the pathogen, but to a lesser extent than the $500 \mathrm{ppm}$ treatment. With regard to plant height, all the treatments showed a decrease in plant size, except the $500 \mathrm{ppm}$ nanoemulsion and chemical control treatments (Figure 4b).

The plants inoculated with Forl (PUCVToF 1667) with the 500 ppm treatment, showed a decrease in the advance of the disease, being statistically equal to the negative control treatment (Figure 5a). The plants with 125 and $250 \mathrm{ppm}$ nanoemulsion treatments also showed a decrease in the advance of the pathogen in comparison to untreated, inoculated control plants. With regard to plant height, all the treatments showed a decrease in the size of the plants, with the exception of the $500 \mathrm{ppm}$ nanoemulsion treatment (Figure $5 \mathrm{~b}$ ). 
a)

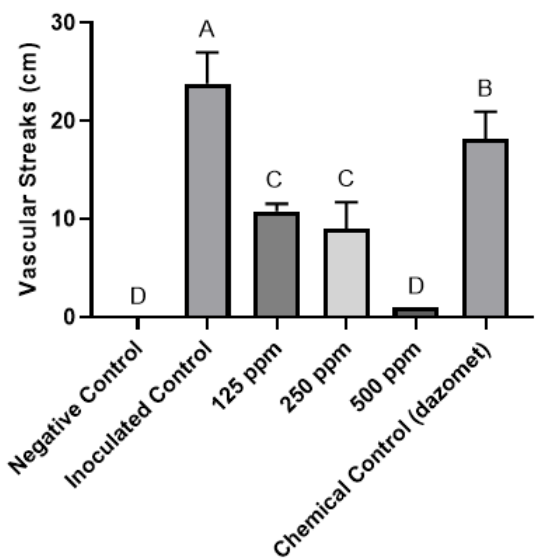

b)

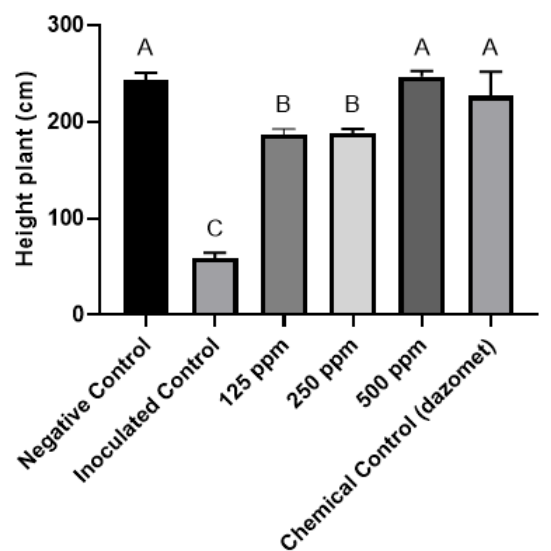

Figure 4. (a) Effect of the different concentrations of nanoemulsion (ppm) on the length (cm) of the vascular streaks observed in 'Naomi' tomatoes inoculated with Forl (PUCVToF 1915). (b) Effect of the different concentrations of nanoemulsion (ppm) on plant height $(\mathrm{cm})$ of 'Naomi' tomatoes inoculated with Forl (PUCVToF 1915). Means with different letters indicate significant differences from each other $(p \leq 0.05)$.

a)

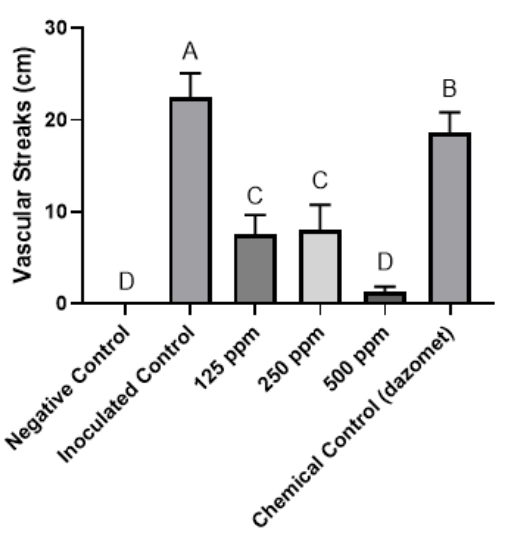

b)

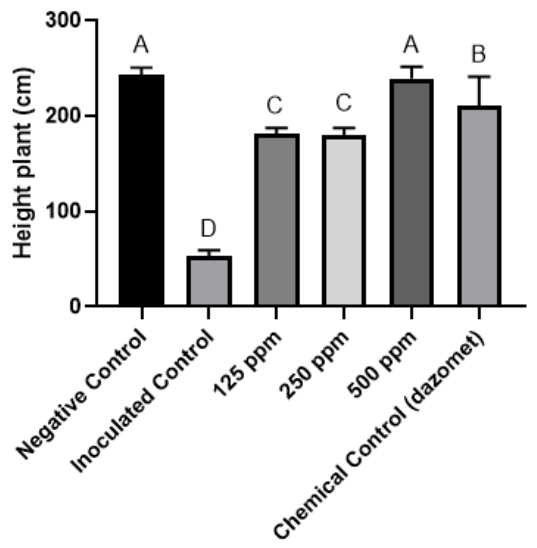

Figure 5. (a) Effect of the different concentrations of nanoemulsion (ppm) on the length (cm) of the vascular streaks observed in 'Naomi' tomatoes inoculated with Forl (PUCVToF 1667). (b) Effect of the different concentrations of nanoemulsion $(\mathrm{ppm})$ on plant height $(\mathrm{cm})$ of 'Naomi' tomatoes inoculated with Forl (PUCVToF 1667). Means with different letters indicate significant differences from each other $(p \leq 0.05)$.

\section{Discussion}

The fungal isolates obtained from the LF-PUCV showed results consistent with the Forl race plus a new or mixture of races between $\mathrm{Fol}+2$ and Forl which has an additional band (Table 1, Figure 1), and has the same capacity to produce damage, which is contrary to the expected result as explained by Hirano and Arie [37]. However, both strains were pathogenic and showed similar behaviors in terms of symptoms and effects in the different treatments, therefore both should be considered as Forl isolates.

Plant extracts have great potential given their various origins and capacities for inhibiting mycelial growth, spore germination and control over viability of conidia. Nanoemulsions formulated from these plant extracts can be more efficient in controlling pathogens than control with conventional chemicals. 
Plant extracts can be used in aqueous or powdered forms [40], or used along with solvents to obtain different compounds, depending on their polarity [41,42]. Among their relatively low-cost advantages, they are also more environmentally friendly and less antagonistic to human health [9].

Researchers evaluating the potential phytotoxicity of plant extracts have shown that systemic application has an effect against $F o l$ [27]. A study with extracts from plant leaves in the Asteraceae family demonstrated control of Fol using these plant extracts, which were found to be $90 \%$ effective in vitro, when compared with a reference agrochemical [43]. This is in accordance with the results obtained in this study.

López-Benítez et al. [27], verified inhibition of Fusarium oxysporum in vitro at $92 \%$ using extracts from Cinnamomum zeylanicum, and at $100 \%$ using Larrea tridentata extract, similar to results obtained by Pérez-Leal et al. [9] using extracts from garlic with 95\% inhibition, and in this study, using plant extract 4, based on Psoralea and Escallonia plants, demonstrating over $80 \%$ inhibition.

According to Bowers and Locke [44], extracts from Piper nigrum, Cassia angustifolia and Syzygium aromaticum suppress the development of disease by $80 \%$, which is similar to the results obtained using the Psoralea and Escallonia extracts in this study. Sharma et al. [32] used nanoemulsions from plant extracts for in vivo studies on controlling Fol, and found disease severity was reduced by up to $70 \%$, a value close to the $73 \%$ reduction achieved in this study. This is also similar to the garlic extract (var. Rio Sonora) which provides tolerance to Fol [11].

Another study using a nanoemulsion based on Opuntia joconostle, at a concentration of $150 \mu \mathrm{L}$, demonstrated an increased percentage of inhibition, at $68 \%$ [33], while still being lower than the $73 \%$ observed in this study. In turn, nanoemulsions at concentrations of $3000 \mathrm{mg} \cdot \mathrm{L}^{-1}$ reached over $90 \%$ inhibition, reaching up to $100 \%$ with increasing concentrations [32].

Sharma et al., [32] also recorded greater control of the disease with the use of carbendazim $\left(1000 \mathrm{mg} \cdot \mathrm{L}^{-1}\right)$ compared to the $57 \%$ obtained in this trial using dazomet $\left(35 \mathrm{~g} \cdot \mathrm{m}^{-2}\right)$. Although this decreases damage to the plants from Forl, the recommended dosage of the fungicide implies higher risks of damage to the environment and to the applicator, as well as a higher cost per hectare.

\section{Conclusions}

This study is the first report using nanoemulsions of native plant extracts affecting Fusarium oxysporum f.sp. radicis-lycopersici (Forl). Plant extract 4 , based on a plant of the genus Psoralea, influenced the in vitro control of Forl conidia, reducing their viability compared to the other extracts evaluated. The nanoemulsion formulated based on this extract effectively controlled fusariosis in tomatoes caused by Forl under greenhouse conditions, reducing the damage to the plants, compared to the inoculated control plants. An increase in the concentration of the extracts leads to greater control of the disease.

These results may indicate that the nanoemulsion from plants of the Fabaceae family could be considered a new biological control product for the future. However, these nanoemulsions must be tested under field conditions to verify the biocontrol ability under agricultural soils. Furthermore, this study should be expanded to identify the method of action this nanoemulsion has on the pathogen.

\section{Patents}

Nanoemulsions based on plant extracts were entered into the INAPI registry for intellectual protection of this technology. Chilean Patent Application No. 202003396.

Author Contributions: Conceptualization, R.A., I.M. and X.B.; methodology, R.A., I.M., M.V., A.M. and X.B.; software, R.A.; validation, E.O., W.B.; formal analysis, X.B., I.M., and E.O.; investigation, R.A.; resources, X.B. and I.M.; writing-original draft preparation, R.A., X.B., N.R., A.S., M.V., E.O., W.B., Y.O., A.M., M.A. and I.M.; writing-review and editing, R.A., N.R., M.A., X.B. and I.M.; 
visualization, R.A., X.B. and I.M.; supervision, X.B.; project administration, X.B.; funding acquisition, I.M. All authors have read and agreed to the published version of the manuscript.

Funding: FONDECYT INICIO This research was funded by Fondecyt grant 11160509 and ANID/PIA/APOYO AFB180002, for the partial funding of this study.

Institutional Review Board Statement: Not applicable.

Informed Consent Statement: Not applicable.

Data Availability Statement: The data presented in this study are available on request from the corresponding author.

Acknowledgments: We also thank Iván Cortes and Francisca Córdova for providing technological assistance. Finally, thank Mary Hopkins for translating this work into English.

Conflicts of Interest: The authors declare the following financial interests/personal relationships which may be considered as potential competing interests: Iván Montenegro, Ximena Besoain, Miryam Valenzuela, Yusser Olguín and Alejandro Madrid are co-inventors of Patent Request NŶ 202003396 of 28 December 2020.

\section{References}

1. Caracterización Económica de la Cadena Agroalimentaria del Tomate de Uso Industrial. Available online: https: / www.odepa. gob.cl/wp-content/uploads/2019/02/TomateIndustrial_2018.pdf (accessed on 4 February 2020).

2. The World's Leading Producers of Tomatoes. Available online: https://www.worldatlas.com/articles/which-are-the-world-sleading-tomato-producing-countries.html (accessed on 22 January 2020).

3. Carbonell, C.; Cifuentes, D.; Tello, J.; Cenis, J. Fusarium oxysporum f. sp. lycopersici and F. o. F. sp. radicis-lycopersici and its detection in plant using RAPD markers. Bol. San. Veg. Plagas 1994, 20, 919-926.

4. Attitalla, H.; Fatehi, J.; Levenfors, J.; Brishammar, S. A rapid molecular method for differentiating two special forms (lycopersici and radicis-lycopersici) of Fusarium oxysporum. Mycol. Res. 2004, 108, 787-794. [CrossRef] [PubMed]

5. Ozbay, N.; Newman, S. Fusarium crown and root rot of tomato and control methods. Plant Pathol. J. 2004, 3, 9-18. [CrossRef]

6. Enespa, S.; Dwivedi, S.K. Effectiveness of some Antagonistic fungi and botanicals against Fusarium solani and Fusarium oxysporum f. sp. lycopersici infecting brinjal and tomato plants. Asian J. Plant Pathol. 2014, 8, 18-25. [CrossRef]

7. Singh, P.; Singh, J.; Ray, S.; Rajput, R.S.; Vaishnav, A.; Singh, R.K.; Singh, H.B. Seed biopriming with antagonistic microbes and ascorbic acid induce resistance in tomato against fusarium wilt. Microbiol. Res. 2020, 237, 126482. [CrossRef] [PubMed]

8. Apodaca, M.; Zavaleta, E.; Osada, S.; García, R.; Valenzuela, J. Hospedantes asintomáticos de Fusarium oxysporum Schlechtend. f. sp. radicis lycopersici W.R. Jarvis y Shoemaker en Sinaloa, México. Rev. Mex. Fitopatol. 2004, 22, 7-13.

9. Pérez-Leal, R.; Villa-Martinez, A.; Morales, H.; Basurto-Sotelo, M.; Soto-Parra, J.; Martínez-Escudero, E. Current situation of Fusarium spp. in the control and evaluation of the antifungal activity on vegetables extracts. Acta Agron. 2014, 64, $194-205$.

10. Lagopodi, A.; Ram, A.; Lamers, G.; Punt, P.; Van den Hodel, C.; Lugtenberg, B.; Bloemberg, G. Novel aspects of tomato root colonization and infection by Fusarium oxysporum f. sp. radicis-lycopersici revealed by confocal laser scanning microscopic analysis using the green fluorescent protein as a marker. Mol. Plant-Microbe Interact. 2001, 15, 172-179. [CrossRef]

11. Aguilar-Gastélum, I.; Martínez Téllez, M.; Corrales-Maldonado, C.; Vargas-Arispuro, I.; Arellano-Gil, M. Induction of defense response in tomato plants against Forl by garlic extract. Rev. Mex. Fitopatol. 2018, 36, 394-413. [CrossRef]

12. Stanghellini, M.; Rasmussen, S. Hydroponics: A solution for zoosporic pathogens. Plant Dis. 1994, 78, 1129-1138. [CrossRef]

13. Ramyabharathi, S.A.; Meena, B.; Raguchander, T. Induction of chitinase and $\beta-1,3$-glucanase PR proteins in tomato through liquid formulated Bacillus subtilis EPCO 16 against fusarium wilt. J. Today Biol. Sci. Res. Rev. 2012, 1, 50-60.

14. García, C.; Ruíz, C.; Palmero, D.; de Cara, M.; Díaz, M.; Camacho, F.; Tello, J. Comportamiento de patrones de tomate frente a la patogenicidad de Fusarium oxysporum f. sp. radicis-lycopersici. In Proceedings of the XIII Congreso de ciencias Hortícolas, Almería, Spain, 16-20 April 2012.

15. Manual de Cultivo del Tomate al Aire Libre. Available online: http:/ /www.inia.cl/wpcontent/uploads/ManualesdeProduccion/ 11\%20Manual\%20Tomate\%20Aire\%20Libre.pdf (accessed on 4 February 2020).

16. Herrera, R. Estudio Etiológico de Fusarium Oxysporum en Tomate en la Zona Central de Chile. Ph.D. Thesis, Universidad de Chile, Santiago, Chile, 2017.

17. Sepúlveda-Chavera, G.; Huanca, W. First report of Fusarium oxysporum f. sp. lycopersici race 3 and F. oxysporum f. sp. radicislycopersici in tomatoes in the Azapa valley of Chile. Plant Dis. 2014, 98, 1432. [CrossRef] [PubMed]

18. Salvador, O.; Staltari, S.; Chorzempa, S.E.; Astiz, M.; Molina, M. Biological control of Fusarium graminearum: Use of Trichoderma spp. and biofumigation with aerial part of Brassica juncea. Rev. Fac. Cienc. Agrar. Univ. Nac. Cuyo. 2014, 46, 45-57.

19. Van den Bosch, F.; Paveley, N.; Van den Berg, F.; Hobbelen, P.; Oliver, R. Mixtures as a Fungicide resistance management tactic. Phytopathology 2014, 104, 1264-1273. [CrossRef] [PubMed]

20. McGovern, R. Management of tomato diseases caused by Fusarium oxysporum. Crop Prot. 2015, 73, 78-92. [CrossRef] 
21. Louws, F.J.; Suchoff, D.; Kressin, J.; Panthee, D.; Driver, J.; Gunter, C. Integrating grafting and emerging products to manage soilborne diseases of tomato. Acta Hort. 2018, 1207, 249-254. [CrossRef]

22. Kim, J.; Jiypung, K. Inhibitory effect of algal extracts on mycelial growth of the tomato-wilt pathogen, Fusarium oxysporum $\mathrm{f}$. sp. lycopersici. Mycobiology 2008, 36, 242-248. [CrossRef]

23. Avendaño, C.; Arbeláez, G.; Rondón, G. Biological control of Phaseolus vulgaris bean vascular wilt caused by Fusarium oxysporum f. sp. phaseoli with combined Entrophospora colombiana, Trichoderma sp. and Pseudomonas fluorescens action. Rev. Agron. Colom. 2006, $24,62-67$.

24. Montenegro, I.; Madrid, A.; Cuellar, M.; Seeger, M.; Alfaro, J.; Besoain, X.; Martínez, J.; Ramirez, I.; Olguín, Y.; Valenzuela, M. Biopesticide activity from drimanic compounds to control tomato pathogens. Molecules 2018, 23, 2053. [CrossRef]

25. Alzate, D.; Mier, G.; Afanador, L.; Durango, D.; García, C. Evaluation of phytotoxicity and antifungal activity against Colletotrichum acutatum of essential oils of thyme (Thymus vulgaris), lemongrass (Cymbopogon citratus), and its main constituents. Rev. Qui. Farm. 2008, 16, 116-125.

26. Alanazi, S.; Alnoman, M.; Banawas, S.; Saito, R.; Sarker, M.R. The inhibitory effects of essential oil constituents against germination, outgrowth and vegetative growth of spores of Clostridium perfringens type A in laboratory medium and chicken meat. Food Microbiol. 2018, 73, 311-318. [CrossRef]

27. López-Benítez, A.; López-Betancourt, S.; Vázquez-Badillo, M.; Rodríguez-Herrera, S. Inhibición del Crecimiento Micelial de Fusarium oxysporum Schlechtend. f. sp. lycopersici (Sacc.) Snyder y Hansen, Rhizoctonia solani Kühn y Verticillium dahliae Kleb. Mediante Extractos Vegetales Acuosos. Rev. Mex. Fitopatol. 2005, 23, 183.

28. Pal, K.K.; McSpadden, B.G. Biological Control of Plant Pathogens. Plant Health Instr. 2006, 5. [CrossRef]

29. Alamri, S.; Hashem, M.; Mostafa, Y.S.; Nafady, N.; Abo-Elyours, K. Biological control of root rot in lettuce caused by Exserohilum rostratum and Fusarium oxysporum via induction of the defense mechanism. Biol. Control 2019, 128, 76-84. [CrossRef]

30. Shen, Z.; Xue, C.; Penton, C.R.; Thomashow, L.; Zhang, N.; Wang, B.; Ruan, Y.; Li, R.; Shen, Q. Suppression of banana Panama disease induced by soil microbiome reconstruction through an integrated agricultural strategy. Soil Biol. Biochem. 2019, 128, 164-174. [CrossRef]

31. Gogoi, R.; Dureja, P.; Singh, P.K. Nanoformulations-A safer and effective option for agrochemicals. Indian Farming 2009, 59, 7-12.

32. Sharma, A.; Sharma, N.K.; Srivastava, A.; Kataria, A.; Dubey, S.; Sharma, S.; Kundu, B. Clove and lemongrass oil based non-ionic nanoemulsión for suppressing the growth of plant pathogenic Fusarium oxysporum f. sp. lycopersici. Ind. Crops Prod. 2018, 123, 353-362. [CrossRef]

33. Santos-Ordoñez, N.; Reyes-Munguía, A.; Hernández-Fuentes, A.D.; Almaraz-Buendía, I.; Campos-Montiel, R.G.; CenobioGalindo, A. Efecto de compuestos bioactivos nanoencapsulados contra hongos de interés agroalimentario. Inv. Des. Cien. Tec. Alim. 2019, 4, 118-124.

34. Park, J.Y.; Kim, S.H.; Kim, N.H.; Lee, S.W.; Jeun, Y.C.; Hong, J.K. Differential inhibitory activities of four plant essential oils on in vitro growth of Fusarium oxysporum f. sp. Fragariae causing fusarium wilt in strawberry plants. Plant Pathol. J. 2017, 33, 582-588. [CrossRef] [PubMed]

35. Abd-Elsalam, K.A.; Khokhlov, A.R. Eugenol oil nanoemulsion: Antifungal activity against Fusarium oxysporum f. sp. vasinfectum and phytotoxicity on cottonseeds. Appl. Nanosci. 2015, 5, 255-265. [CrossRef]

36. Nash, S.M.; Snyder, W.C. Quantitative estimations by plate counts of propagules of the bean root rot Fusarium in field soils. Phytopathology 1962, 52, 567-572.

37. Hirano, Y.; Arie, T. PCR-based differentiation of Fusarium oxysporum f. sp. lycopersici and radicis-lycopersici and races of F. oxysporum f. sp. lycopersici. J. Gen. Plant Pathol. 2006, 72, 273-283. [CrossRef]

38. Sonneveld, C. Fertigation in the greenhouse industry. In Proceedings of the Dahlia Greidinger International Symposium on Fertigation, Technion Institute of Technology, Haifa, Israel, 25 March-1 April 1995.

39. Paulus, O. Fusarium crown and root rot. In Compendium of Tomato Diseases; Jones, J.B., Jones, J.P., Stall, R.E., Zitter, T.A., Eds.; APS Press: Eagan, MN, USA, 1997; p. 14.

40. Bautista, S.; Hernández, M.L.; Bosquez, E.M.; Wilson, C.L. Effects of chitosan and plant extracts on growth of Colletotrichum gloeosporioides, anthracnose levels and quality of papaya fruti. Crop Prot. 2003, 22, 1087-1092. [CrossRef]

41. Abou-Jawdah, Y.; Sobh, H.; Salameh, A. Antimycotic activities of selected plant flora, growing wild in Lebanon, against phytopathogenic fungi. J. Agric. Food Chem. 2002, 50, 3208-3213. [CrossRef] [PubMed]

42. Kliebenstein, D.J. Secondary metabolites and plant/environment interactions: A view through Arabidopsis thaliana tinged glasses. Plant Cell Environ. 2004, 27, 675-684. [CrossRef]

43. Jasso de Rodríguez, D.; Hernández-Castillo, D.; Angulo-Sánchez, J.L.; Rodríguez-García, R.; Villarreal-Quintanilla, J.A.; LiraSaldivar, R.H. Antifungal activity in vitro of Flourensia spp. Extracts on Alternaria sp., Rhizoctonia solani, and Fusarium oxysporum. Ind. Crops Prod. 2007, 25, 111-116. [CrossRef]

44. Bowers, J.; Locke, J.C. Effect of botanical extracts on the population density of Fusarium oxysporum in soil and control of fusarium wilt in the greenhouse. Plant Dis. 2000, 84, 300-305. [CrossRef] [PubMed] 